\title{
ASSESSMENT OF PLANT DIVERSITY INDICES OF GOMATI RIPARIAN CORRIDORS IN DISTRICT JAUNPUR, INDIA
}

\author{
Mayank Singh and M.P. Singh* \\ Department of Botany, T.D.P.G. College, Jaunpur-222002, U.P., India \\ *Email: mahendrapratapsinghtdpg@gmail.com
}

\begin{abstract}
Riparian ecosystems, the central elements in many landscapes, are described as an ecotone stretched out across the landscape because of their shape diversity and function as filters and corridors still they are most disturbed and threatened by humans. The present work deals with seasonal dynamics in plant diversity indices at two distinct sites (I and II) at ecotonal belts of River Gomati, Jaunpur (U.P.). The diversity indices of plant community have been computed on the basis of density values recorded from April, 2012 to March, 2013. Site I showed more species richness and evenness as compared to site II. Shannon and Weaver, Evenness, Marglef's, McIntosh and Menhinic diversity indices values were higher at site I compared to site II. In contrast, the concentration dominance showed higher value at site II, whereas Simpson values of diversity have fluctuated in different seasons at both the sites (I and II). It finally deals to formulate strategies and methods for the management of plant diversity and other natural resources based on various ecological studies, and logical grounds.
\end{abstract}

Key words: Diversity, indices, riparian, wetland, corridors, ecotone, buffer zone, management.

\section{INTRODUCTION}

Jaunpur is an ancient city in eastern U.P. and is respected for its cultural heritage. River Gomati bisects the city of Jaunpur $\left(25^{\circ} 44^{\prime}\right.$ to $25^{\circ} 45 \mathrm{~N}$ lat., $82^{\circ} 42^{\prime}$ to $82^{\circ} 43^{\prime} \mathrm{E}$ long.) in north and south parts. Gomati originates from about $3 \mathrm{~km}$ east near Madho Tada town of Pilibhit U.P. India, at a height of $200 \mathrm{~m}$, from an impounding reservoir known as 'Gomath Tal'. Its extent is $900 \mathrm{~km}$ through U.P. after flowing southwards it confluences with River Ganga at Aundiayar near Saidpur city in Gajzipur district. Gomati is fed in district Jaunpur by tributaries like Pili, Sai. Apart from tributaries various 'Nalas' and irrigation canals for flood relief purposes also join Gomati. The riparian corridors are regarded as cradles of speciation and store house of 'gene pools'. The wetland margins overlapping with adjacent upland margins are called the wetland ecotones. The width of the corridors varies according to topography and water level fluctuation. They enjoy some of the best ecological conditions found in terrestrial and aquatic habitats (Ambasht and Ambasht 2008). The term riparian buffer is used to describe lands adjacent to streams where vegetation is strongly influenced by presence of water. The river margin slope vegetation acts as buffer and sinks against excessive flow of municipal wastes into the water through riparian corridors. The embankment vegetation regarded as "natures treatment system" (Kadlec and Kadlec 1979) or as "Kidneys" (Ambasht 2008) by protecting the main water body 
or river water against input of soil, water, nutrients, pesticides and other pollutants and thus preventing eutrophication. The riparian buffers are important for good water quality. Riparian vegetation slows flood water to soak into the ground and recharge ground water. Depending on the surrounding land use and area of topography, riparian buffer range from 25 to 100 feet wide on each side of the river. Plant diversity refers to the variety of plant species within a region. Man has always been captivated by biological diversity. Species diversity is a component reflecting the number of species (richness) and distribution of individual of all species at particular site (McArthur 1965, Lewis 1970 and Bilgrami 1988).

Whittaker (1960) proposed the division of diversity into alpha $(\alpha)$, beta $(\beta)$ and gamma $(\gamma)$ components. Alpha $(\alpha)$ diversity is within-area diversity as the number of species occurring within an area of a given size (Huston 1994). Beta $(\beta)$ diversity is between area diversity. It shows the degree of species change along a given habitat or physiographic gradient (Wilson and Shmida 1984 and Jenkins 2003). Gamma $(\gamma)$ diversity is also a measure of within area diversity. However, it usually refers to overall diversity within a large region (Norse 1983 and Magurran 2004). Best fit diversity indices were used as recommended by Washington (1984).

Degraded lands may be developed for biodiversity conservation which has been established by Tobias and Mirigam (2011). The present study sites stability, usefulness and sustainability depend on preservation of plant diversity. Despite the importance of tremendous variables of eco tonal areas throughout the world (Johnson and McCormic 1979 and Nilson and Keddy 1988) a very little ecological attention has been focused on such interesting areas in tropical climate like India. It attracts ecologists to explore the comparative variability of plant community diversity indices and management of such degraded wetland ecotones.

\section{MATERIALS AND METHODS}

Study area and climate: Two kinds of habitats on river banks can be distinguished: (1) Abandoned or neglected land $(50 \times 200 \mathrm{~m})$ (2) Cropland or riparian agroecosystem $(75 \times 125 \mathrm{~m})$. They lie on the curved course of Gomati at Rouza Ghat at 10$15^{\circ}$ and $12-17^{\circ}$ of slopes for site I and site II, respectively. On site II mixed crop of wheat and mustard was cultivated during winter season only for four months because of inundation during rainy season and extremely dry condition in summer. Site II remains as fallow land for rest of the periods. Sometime site II during fallow period farmers try to plough the lands for cropping but their efforts usually fail due to inundation during rainy season. The climate was typically monsoonal with three different seasons viz. rainy (July to October), winter (November to February) and summer (March to June). Total rainfall during study period (April, 2012 to March, 2013) was $882.0 \mathrm{~mm}$ out of which $809.8 \mathrm{~mm}$ was in the rainy season. The soil was sandy, loose and alkaline with $\mathrm{pH}$ from 7.2 to 8.8 .

\section{Vegetation sampling and computation}

Findings are based on line transect method through $50 \mathrm{~cm} \times 50 \mathrm{~cm}$ quadrat laid at every one metre alternative segments from top up land to lower river margin seasonally. Plants were noted and identified. Diversity indices were calculated by plant density values of both the sites (I and II) as follows:

a) Simpson's index (Simpson 1949) was calculated by formula:

$\mathrm{D}=\sum \frac{\mathrm{ni}(\mathrm{ni}-1)}{\mathrm{N}(\mathrm{N}-1)}$

where,

$\mathrm{ni}=$ number of individuals of $\mathrm{i}^{\text {th }}$ species and

$\mathrm{N}=$ total number of individuals of all species.

ECOPRINT VOL 20, 2013 
b) Shannon index of diversity also referred as Shannon-Weaver and Shannon-Wiener index $\left(\mathrm{H}^{\prime}\right)$ given by Shannon and Weaver (1949) and modified by Shannon and Weaver (1964):

$$
\mathrm{H}^{\prime}=3.321 \sum_{\mathrm{N}}^{\mathrm{ni}} \log \frac{\mathrm{n}}{\mathrm{i}} \mathrm{N}
$$

where,

ni $=$ number of individuals of $i^{\text {th }}$ species and $\mathrm{N}=$ Total number of individuals of all species.

c) Evenness (E) was computed from Pielou's index (Pielou, 1969):

$$
\mathrm{E}=\frac{\mathrm{H}^{\prime}}{\mathrm{In} \mathrm{S}}
$$

where,

$\mathrm{H}^{\prime}=$ Shannon Wiener diversity and

$\ln S=$ Natural $\log$ of the total number of species recorded.

d) Concentration of dominance (Cd) was calculated by using following formula given by Simpson (1949):

$\mathrm{Cd}=(\mathrm{Ni} / \mathrm{N})^{2}$

where,

$\mathrm{S}=$ Number of species in collection,

$\mathrm{Ni}=$ Proportion of individuals belonging to $i^{\text {th }}$ species

$\mathrm{N}=$ Total number of individuals of the stand.

$\mathrm{Cd}=(\mathrm{Ni} / \mathrm{N})^{2}$

e) Marglef's community diversity index (d') which is based on Marglef's information theory (1968), Odum (1971), Hutchinson (1957) and Bilgrami (1988).

$$
\mathrm{d}^{\prime}=\frac{\mathrm{s}-1}{\log \mathrm{N}}
$$

where,

$\mathrm{d}=$ Marglef's Index,

$\mathrm{s}=$ Number of species

$\mathrm{N}=$ Total number of individuals in community.

\section{f) McIntosh diversity Index (DI)}

The diversity index (DI) of the community was calculated by using the formula suggested by McIntosh (1967):

$\mathrm{d}=\mathrm{S} / \sqrt{ } \mathrm{N}$

where,

$\mathrm{i}=1$,

$\mathrm{S}=$ Number of species

$\mathrm{n}=$ Number of individuals of each species.

g) Menhinic Index of diversity (DI):

Menhinic (1964) has given following formula:

$\mathrm{d}=\mathrm{S} / \sqrt{\mathrm{N}}$

Where,

$\mathrm{d}=$ Diversity index,

$\mathrm{S}=$ Number of species and

$\mathrm{N}=$ Number of individuals.

Statistical analysis: Statistical analysis was performed using Graphpad Prism software. Data were expressed as mean value \pm SD. Significant differences between data groups were determined using student t-test and $\mathrm{p}<0.05$ was considered significant.

\section{RESULTS AND DISCUSSION}

Species diversity is important as it is assumed as index of survival value of community or its relative stability status. The differences in interspecific associations, the biotic composition of two plant communities are never exactly alike. They may resemble in physiognomy, may have the same dominants but even then like two members of the same family they will differ and show differences in species composition. The attributes of seasonal variation in diversity indices of plant community at two study sites (I and II) have been depicted in Fig. 1. The value of Simpson index at site I had varied from 0.25 (summer) to 0.43 (winter), in contrast at site II the values were from 0.36 (summer) to 0.38 (winter). The average value of the same index was 0.35 (site I) and 0.36 (site II). The Shanon Wiener function, specie's richness and equability values 
were maximum at site I (3.57) and at site II (2.58) both during rainy season. In contrast, their respective lowest values were 2.32 site I and 2.26 both during the winter season. The average value of same was more at site I (3.00) in comparison to site II (2.41). However, evenness peak values were 0.81 (winter) and 0.61 (summer) at two respective sites I and II. The respective minimum values were 0.79 (summer) 0.38 (winter). The average value of evenness 0.80 (site I) and 0.48 (site II).

At site $\mathrm{I}$, the concentration of dominance index ranged from minimum of 0.23 (summer) to maximum of 0.28 (winter). In contrast, at site II the value ranged from 0.38 (summer) to 0.40 (winter). The average value of concentration dominance at study sites I and II was 0.25 and 0.40 , respectively. The Marglef's index value have ranged from minimum of 11.29 at site I and 7.35 at site II both in the summer season, whereas its maximum values were 17.57 and 10.18 at the two respective sites I and II both during rainy season.

The McIntosh diversity index values at site I ranged from 2537.12 (summer) to 5281.14 (rainy). In contrast the respective values at site II were 1171.67 (summer) to 3936.20 (winter). The average value 3833.01 was higher at site $\mathrm{I}$ in comparison to site II (2732.86). Menhinic diversity index peak values were 0.51 (rainy) at site I and 0.42 (summer) at site II. Their respective minimum values at the two sites were 0.49 and 0.27 both during winter season. The average value of the same was higher (0.50) at site I in comparison to (0.36) at site II (Fig. 1).

Our study findings of plant diversity indices at two selected sites (I and II) seems to be useful parameter for comparison of two communities. The diversity on both the sites (I and II) is more or less slightly lower during summer season when extremely dry conditions prevail. During rainy and post rainy season on site I and fallow land of site II, diversity is high. Soil moisture also seems to have a direct effect on the diversity index of vegetation. In fact, greater diversity provides a number of alternative pathways in ecosystem functioning that give stability to the ecosystem. It also appears that nature usually favors high species diversity man while prefers monoculture and brings uniformity. Natural communities of riparian corridors of site I, (neglected wasteland) with slightly higher species of diversity are less vulnerable and seems to be more stable in comparison to site II (winter crop cultivated riparian agro ecosystem) which is more or less in seral stages and mostly occupied by developing communities due to more biotic disturbances.

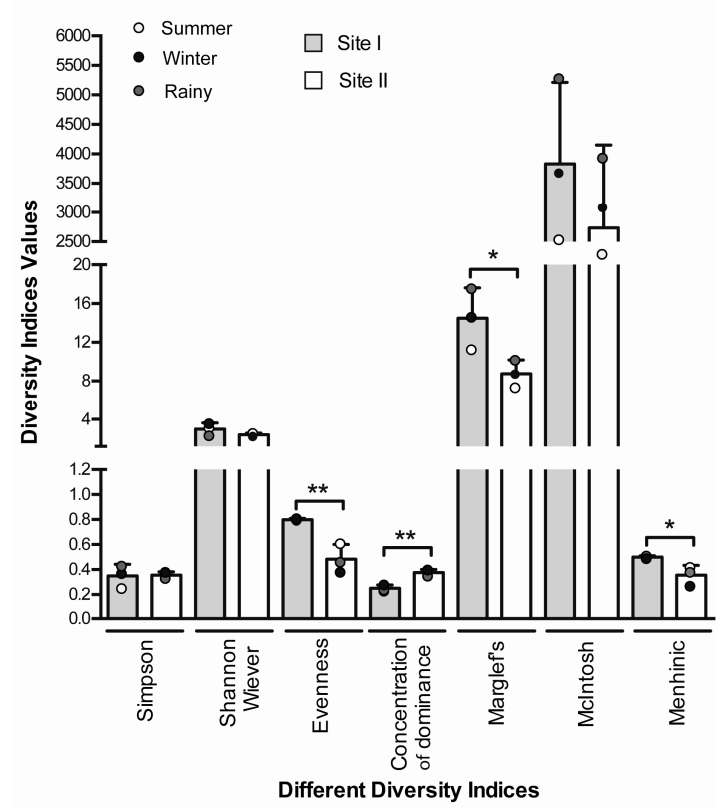

Fig. 1. Seasonal variation in diversity indicies values of plant community at two different sites (I and II). Solid bars: indices values at site I; Open bars: indices values at site II. Indices values during summer (black), rainy (grey) and winter (white) are shown with filled circles. Results are presented as mean \pm SD. $p$ values were determined using unpaired student's t-tests (* indicates $\mathbf{p}<0.05$ and $* *$ indicates $\mathbf{p}$ $<0.01)$. 
In the present study higher number of species (73) at site I in comparison to site II (53) reflect the higher values of Shannon Wiever indices. It seems to be controlled more by species richness and also by equitability (evenness). The evenness was also maximum at site I in comparison to site II which is usually used for winter cropping and man made biotic forces are more operative. The results also indicate that Marglef's, McIntosh and Menhinic diversity index values were also higher at site I in comparison to site II. Maximum concentration of dominance at site II (but low species) richness reflects the dominance of few species only. Simpson values of indices have fluctuated during different seasons but it was slightly higher at site II in comparison to site I. It might be due to slight variation in concentration of nutrients at the two sites. During summer season, the diversity values were more or less slightly lower at both the sites (I and II). Soil moisture also seems to have direct effect on the diversity index of vegetation.

Statistical analysis in the present study clearly indicates that there was a significant difference in the diversity indices values (for evenness $\mathrm{p}=0.0094$, concentration of dominance $\mathrm{p}=0.0039$, Marglef's community $\mathrm{p}=0.0451$ and Menhinic diversity indices $\mathrm{p}=0.0339$ ) of two sites ( $\mathrm{I}$ and II) suggesting the differences in the plant diversity of above sites.

Usefulness of plant diversity in eco-reforms and management: Degraded riparian corridors sustainability is dependent upon the preservation of plant diversity. In order to manage sensibly sustained stability of riparian buffers landmanagers, planners and field staff must recognize "functional diversity" of such wetland ecotones as human beings get benefitted through plant diversity. The diversity of plant provides economic, social and cultural values and many of ecological services free of charge. This will be greatly beneficial for the restoration of ecological balance and sustainable utilization for the local inhabitant without whom there will not be available a sense of 'share and care'.

If riparian corridors plant diversity is managed properly it may lead to material benefit of the mankind and these native diversities may serve as source of pride and plant diversity can promise good environment in near future.

\section{ACKNOWLEDGEMENTS}

The authors extend their cordial thanks to Dr.S.K.Singh, Retd. Prof. and Head of Department of Botany, D.D.U. University, Gorakhpur for his valuable help in identification of some of plants of study sites. I would also like to thank the Principal T.D. (P.G.) College, Jaunpur for his help and encouragement.

\section{REFERENCES}

Ambasht, R.S. 2008. Wetland ecology, an overview. Proc. National Acad. Sci. India. 78:3-12.

Ambasht, R.S., M.P. Singh and E. Sharma. 1984. Soil, water and nutrient conservation by certain riparian herbs. J. Environmental Management. 18:99-104.

Ambasht, R.S. and N.K. Ambasht. 2008. Landwater ectone ecology. Proc. Nat. Acd. Sci. India, Sect. (Biological Sciences), special issue, Wetland ecology, (ed.) R.S. Ambasht. pp. 99-105.

Bilgrami, K.S. 1988. Dynamics of phytoplanktonic, fluctuations in a lentic water body. In: Aquatic Environment, 1992. (ed.) Ashutosh Gautam. Ashish Publishing, New Delhi, pp.60.

Huston, M.A. 1990. Biological Diversity: The Coexistence of Species on Changing Landscapes. Cambridge University Press, Cambridge.

Hutchinson, G.E. 1957. A Treatise in Limnology, Geography, Physics and Chemistry, Vol. I. John Wiley and Sons, New York. 1015 pp. 
Jenkins, M. 2003. Prospects of biodiversity. Science. 302:1175-1177.

Johnson, R.R. and J.F. McCormic. 1979. Strategies for protection and management of flood-plain wetlands and other riparian ecosystems, (eds.) U.S. Deptt. Agric. Forest Serv. Gen. Tech. Rep. NO.WO-12.

Kadlec, R.H. and J.A. Kadlec. 1979. Wetlands and water quality. In: Wetlands Foundations and Values: The State of Our Understanding. (eds.) Greeson, P.E., J.R. Clark and J.E. Clark. American Water Association, Minneapolis, pp. 436-546.

Lewis, J.K. 1970. Production in grassland ecosystem US/IBP. Grassland Ecosystem: A Supplement. (eds.) Dix, R.L. and R.C. Beidleman. Colorado State University, USA.

Magurann, A.E. 2004. Measuring Biological Diversity. Blackwell, Oxford, Publ. USA.

Marglef, R. 1968. Perspectives in Ecological Theory. University of Chicago Press, 112 pp.

McArthur, R.H. 1965. Patterns of species diversity. Biological Review 40:510-533.

McIntosh, R.P. 1967. The continum concept of vegetation. Bot. Rev. 33:130-187.

Menhinic, E.F. 1964. A comparision of some species diversity indicies applied to samples of field insects. Ecology 45:858-862.

Nilsson, C. and P.A. Keddy. 1988. Predictability of change in shoreline vegetation in a hydroelectric reservoir, northern Sweden, Can. J. Fish. Aquat. Sci. 45:1896-1904.

Norse, R.F. 1983. A regional landscape approach to maintain diversity. Bioscience 33:700-706.

Odum, E.P. 1971. Fundamental of Ecology 3rd edn. W.B. Saunders and Co. Philadelphia, 574 pp.

Pielou, E.C. 1969. An Introduction to Mathematical Ecology. John Wiley and Sons, New York.
Shannon, C.E. and W. Weaver. 1949. The Mathematical Theory of Communication. Urbana University, Illinois Press, 117 pp.

Shannon C.E. and W. Weaver. 1964. The Mathematical Theory of Communication. The University of Illinois, Press, Urbana, IL.

Simpson, E.H. 1949. Measurement of diversity. Nature pp. 163-188.

Singh, M.P. 1996. Gomati water pollution and health hazards. Proceedings of National Seminar on Social Pollution and Human Life. Jaunpur. Sahkari P.G. College, Mehrwawan, Jaunpur (U.P.). pp. 119-123.

Singh, M., O.P. Singh 'Vatsa' and M.P. Singh. 2011. Impact of natural rainfall events on the conservation of soil, water and nutrients by vegetational cover at Gujar lake margin. Indian J. Ecology 38(1):67-72.

Singh, M., M.P. Singh and O.P. Singh. 2006. Conservation of biodiversity of wetlands of Jaunpur (U.P.) Proceedings of National Conference on Global Pollution a Serious Threat to Indian Biodiversity. S.B.P.G. College, Baragaon, Varanasi, U.P. pp. 71-83.

Tobias, P. and G. Mirijam. 2011. Harnessing degraded lands for biodiversity conservation. Journal for Nature Conservation, 19:18-23.

Washington, H.E. 1984. Diversity, biotic and similarity indices: a review with special relevance to aquatic ecosystem. Water Res. 18:653-694.

Whittaker, R.H. 1960. Vegetation of the Siskiyou Mountains, Oregon and California, Ecological Manographs 30:279-338.

Wilson, M. and A. Schmida. 1984. Measuring beta diversity with presence and absence data. Journal of Ecology 72:1055-1064.

WRI /IUCN/UNEP. 1992. Global Biodiversity Strategey. WRI/IUCN/UNEP, Washington DC. 